\title{
URGENSI UNDANG-UNDANG KETERBUKAAN INFORMASI PUBLIK DALAM MANAJEMEN PEMBANGUNAN EKONOMI
}

\author{
Moh. Rosyid \\ Jurusan Tarbiyah Sekolah Tinggi Agama Islam Negeri Kudus \\ (mrosyid72@yahoo.co.id)
}

\begin{abstract}
The Public Information Commission (KIP) has the role of encouraging information transparency in central and regional government agencies (pemda) and conducting education related to the era of public information disclosure to the public. Consequently, KIP members must work professionally and work optimally so that people feel their existence. This manuscript is a small part of the effort to provide an understanding to the public about the importance of the Public Information Disclosure Act for citizens, especially for economic development. The business world needs information in its entirety, starting from understanding about legislation, government policies under the law, policies of state administrators at the central and regional levels in the economic/ business field, and other aspects. If this is realized, then people's welfare will be realized through development in the field of public information. The full implementation of the KIP Law is highly dependent on the government's performance, citizens' awareness, and the role of civil society as a Nation Government Organization (NGO / NGO) that controls the performance of the government. The role of NGOs can accelerate the realization of an open government which is a strategic effort to prevent the practice of corruption, collusion and nepotism (KKN), the creation of good governance, and the realization of wise public services.
\end{abstract}

Keywords: information, openness, welfare.

BISNIS, Vol. 2, No. 1, Juni 2014 


\section{A. Pendahuluan}

Ragam kebutuhan setiap individu sangat ditentukan oleh profesi, lingkungan, dan gaya hidup dalam rutinitas sehari-hari. Dalam konteks perekonomian, kebutuhan utama individu antara lain adalah sumber informasi sebagai modal mengakses modal, strategi memasarkan produk, mensikapi kompetisi, dan dinamika bisnis. Untuk mewujudkan warga negara yang sejahtera, sudah selazimnya Negara memberi sumber informasi dengan kemudahan bagi pihak manapun yang berkepentingan untuk mengakses informasi berbagai bidang. Hal ini didorong oleh Hak untuk Tahu Internasional (International Right to Know Day) yang diperingati setiap 28 September. Menurut Al-Afghani, transparansi dan kebebasan informasi dianggap sebagai bagian dari hak asasi manusia dan dipercaya mutlak diperlukan dalam suatu negara demokratis untuk membasmi korupsi. Transparansi dan akses informasi diperlukan agar pasar dapat bekerja secara baik. Agenda transparansi sealur antara lembaga donor internasional dengan gerakan masyarakat sipil. Transparansi demokrasi berkeyakinan bahwa informasi perlu dibuka sebagai salah satu bentuk pertanggungjawaban pemerintah kepada rakyat dan perlunya perlindungan terhadap kerahasiaan (2013:6). Sejak September 2011, delapan negara menginisiatori open government partnership yakni sebuah upaya bersama mewujudkan pemerintahan yang lebih terbuka dan mengajak partisipasi publik. Kedelapan negara tersebut yakni Amerika, Inggris, Meksiko, Indonesia, Filipina, Brasil, Norwegia, dan Afrika Selatan. Perdana Menteri Inggris David Cameron membentuk tim Reformasi dan Efisiensi (ERG) untuk efesiensi dan reformasi anggaran sebagai layanan publik. Komitmen tersebut dalam hal (1) keterbukaan data untuk akuntabilitas, perbaikan layanan publik, dan pertumbuhan ekonomi, (2) integritas pemerintah dalam menanggulangi korupsi melalui transparansi pemerintahan, (3) transparansi fiskal agar rakyat mengetahui peruntukan pajak yang dibayarkan, (4) pemberdayaan warga melalui perubahan cara komunikasi warga dengan pemerintah, (5) transparansi sumber daya alam (SDA) agar pemasukan Negara digunakan untuk kepentingan publik (Kompas, 13 April 2014).

Muatan UUD 1945 Pasal 28 F bahwa setiap orang berhak untuk berkomunikasi dan memperoleh informasi untuk mengembangkan pribadi dan lingkungan sosialnya, serta berhak untuk mencari, memperoleh, memiliki, dan menyimpan informasi dengan menggunakan segala jenis saluran yang tersedia. Untuk memberikan 
jaminan terhadap semua orang dalam memperoleh informasi, UU KIP sangat diperlukan yang berfungsi memenuhi hak warga negara agar terpenuhi informasi. Hal ini merupakan hak asasi manusia sebagai salah satu wujud dari kehidupan berbangsa dan bernegara yang demokratis karena salah satu elemen penting dalam mewujudkan penyelenggaraan negara yang terbuka adalah hak publik untuk memperoleh informasi sesuai dengan peraturan perundangan. Hak atas informasi menjadi sangat penting karena makin terbuka penyelenggaraan negara untuk diawasi publik, penyelenggaraan negara tersebut makin dapat dipertanggungjawabkan. Hak setiap orang untuk memperoleh informasi juga relevan untuk meningkatkan kualitas pelibatan masyarakat dalam proses pengambilan keputusan publik. Partisipasi atau pelibatan masyarakat tidak banyak berarti tanpa jaminan KIP.

Keberadaan UU KIP sangat penting sebagai landasan hukum yang berkaitan dengan (1) hak setiap orang untuk memperoleh informasi; (2) kewajiban Badan Publik (BP) menyediakan dan melayani permintaan informasi secara cepat, tepat waktu, biaya ringan/proporsional, dan cara sederhana; (3) pengecualian bersifat ketat dan terbatas; (4) kewajiban BP untuk membenahi sistem dokumentasi dan pelayanan informasi. Pasal 1 (3) Badan Publik adalah lembaga eksekutif, legislatif, yudikatif, dan badan lain yang fungsi dan tugas pokoknya berkaitan dengan penyelenggaraan negara, yang sebagian atau seluruh dananya bersumber dari Anggaran Pendapatan dan Belanja Negara dan/atau Anggaran Pendapatan dan Belanja Daerah, atau organisasi nonpemerintah sepanjang sebagian atau seluruh dananya bersumber dari Anggaran Pendapatan dan Belanja Negara dan/atau Anggaran Pendapatan dan Belanja Daerah, sumbangan masyarakat, dan/atau luar negeri. Setiap BP mempunyai kewajiban untuk membuka akses atas informasi publik yang berkaitan dengan badan publik untuk masyarakat luas. Lingkup BP dalam UU KIP meliputi lembaga eksekutif, yudikatif, legislatif, serta penyelenggara negara lainnya yang mendapatkan dana dari APBN/APBD dan mencakup pula organisasi nonpemerintah, baik yang berbadan hukum maupun yang tidak berbadan hukum, seperti lembaga swadaya masyarakat (LSM), perkumpulan, serta organisasi lainnya yang mengelola atau menggunakan dana yang sebagian atau seluruhnya bersumber dari APBN/APBD, sumbangan masyarakat, dan/atau luar negeri. Melalui mekanisme dan pelaksanaan prinsip keterbukaan akan tercipta pemerintahan yang baik dan peran serta 
masyarakat yang transparan dan akuntabilitas yang tinggi sebagai salah satu prasyarat mewujudkan demokrasi yang hakiki.

Hak memperoleh informasi merupakan hak asasi manusia dan KIP merupakan salah satu ciri penting negara demokratis yang menjunjung tinggi kedaulatan rakyat untuk mewujudkan penyelenggaraan negara yang baik. KIP merupakan sarana dalam mengoptimalkan pengawasan publik terhadap penyelenggaraan negara dan BP lainnya dan segala sesuatu yang berakibat pada kepentingan publik. Pengelolaan informasi publik merupakan salah satu upaya untuk mengembangkan masyarakat informasi yang dapat dijadikan mengakses dinamika menuju terpenuhinya kebutuhan hidup warga negara, khususnya di bidang ekonomi.

Dengan demikian, disahkannya UU Nomor 14 Tahun 2008 tentang Keterbukaan Informasi Publik (KIP) yang diberlakukan sejak 2010 menjadi hal penting untuk ditelaah sejauhmana realisasinya untuk dijadikan sumber dan pengembangan perekonomian warga.

\section{B. Landasan Teori}

\section{1) Asas dan Tujuan Informasi Publik}

Pasal 2 (1) Setiap Informasi Publik (SIP) bersifat terbuka dan dapat diakses oleh setiap pengguna informasi publik. (2) Informasi Publik (IP) yang dikecualikan bersifat ketat dan terbatas. (3) Setiap Informasi Publik harus dapat diperoleh setiap Pemohon IP dengan cepat dan tepat waktu, biaya ringan, dan cara sederhana. (4) IP yang dikecualikan bersifat rahasia sesuai dengan UU, kepatutan, dan kepentingan umum didasarkan pada pengujian tentang konsekuensi yang timbul apabila suatu informasi diberikan kepada masyarakat serta setelah dipertimbangkan dengan saksama bahwa menutup IP dapat melindungi kepentingan yang lebih besar daripada membukanya atau sebaliknya.

Pasal 3 tujuan IP untuk (a) menjamin hak warga negara untuk mengetahui rencana pembuatan kebijakan publik, program kebijakan publik, dan proses pengambilan keputusan publik, serta alasan pengambilan suatu keputusan publik; (b) mendorong partisipasi masyarakat dalam proses pengambilan kebijakan publik; (c) meningkatkan peran aktif masyarakat dalam pengambilan kebijakan publik dan pengelolaan Badan Publik (BP) yang baik; (d) mewujudkan penyelenggaraan negara yang baik, yaitu yang transparan, efektif dan 
efisien, akuntabel serta dapat dipertanggungjawabkan; (e) mengetahui alasan kebijakan publik yang mempengaruhi hajat hidup orang banyak; (f) mengembangkan ilmu pengetahuan dan mencerdaskan kehidupan bangsa; dan (g) meningkatkan pengelolaan dan pelayanan informasi di lingkungan BP untuk menghasilkan layanan informasi yang berkualitas.

\section{2) Hak Pemohon dan Kewajiban Pengguna Informasi Publik}

Pasal 4 (1) Setiap orang berhak memperoleh IP sesuai ketentuan UU ini, (2) Setiap orang berhak (a) melihat dan mengetahui IP; (b) menghadiri pertemuan publik yang terbuka untuk umum untuk memperoleh IP; (c) mendapatkan salinan IP melalui permohonan sesuai dengan UU KIP; dan/atau (d) menyebarluaskan IP sesuai dengan peraturan perundangan, (3) Setiap Pemohon IP berhak mengajukan permintaan IP disertai alasan permintaan tersebut. (4) Setiap Pemohon IP berhak mengajukan gugatan ke pengadilan apabila dalam memperoleh IP mendapat hambatan atau kegagalan sesuai ketentuan UU KIP. Pasal 5 (1) Pengguna Informasi Publik wajib menggunakan IP sesuai dengan ketentuan perundangan. (2) Pengguna Informasi Publik wajib mencantumkan sumber dari mana ia memperoleh IP, baik yang digunakan untuk kepentingan sendiri maupun untuk keperluan publikasi sesuai dengan ketentuan peraturan perundangan.

\section{3) Hak dan Kewajiban Badan Publik}

Pasal 6 (1) Badan Publik berhak menolak memberikan informasi yang dikecualikan sesuai dengan ketentuan peraturan perundangan. (2) Badan Publik berhak menolak memberikan Informasi Publik apabila tidak sesuai dengan ketentuan peraturan perundangan. (3) Informasi Publik yang tidak dapat diberikan oleh Badan Publik, sebagaimana dimaksud pada ayat 1 adalah (a) informasi yang dapat membahayakan negara; (b) informasi yang berkaitan dengan kepentingan perlindungan usaha dari persaingan usaha tidak sehat; (c) informasi yang berkaitan dengan hak pribadi; (d) informasi yang berkaitan dengan rahasia jabatan; dan/atau (e) Informasi Publik yang diminta belum dikuasai atau didokumentasikan. Pasal 7 (1) Badan Publik wajib menyediakan, memberikan dan/atau menerbitkan Informasi Publik yang berada di bawah kewenangannya kepada Pemohon Informasi Publik, selain informasi yang dikecualikan sesuai dengan ketentuan. (2) Badan Publik wajib menyediakan Informasi Publik yang akurat, benar, dan tidak menyesatkan. (3) Untuk melaksanakan kewajiban sebagaimana 
dimaksud ayat 2, Badan Publik harus membangun dan mengembangkan sistem informasi dan dokumentasi untuk mengelola Informasi Publik secara baik dan efisien sehingga dapat diakses dengan mudah. (4) Badan Publik wajib membuat pertimbangan secara tertulis setiap kebijakan yang diambil untuk memenuhi hak setiap orang atas Informasi Publik. (5) Pertimbangan sebagaimana dimaksud ayat 4 antara lain memuat pertimbangan politik, ekonomi, sosial, budaya, dan/atau pertahanan dan keamanan negara. (6) Dalam rangka memenuhi kewajiban sebagaimana dimaksud ayat 1 s.d 4 Badan Publik dapat memanfaatkan sarana dan/atau media elektronik dan nonelektronik. Pasal 8 Kewajiban Badan Publik yang berkaitan dengan kearsipan dan pendokumentasian Informasi Publik dilaksanakan berdasarkan peraturan perundangan.

\section{4) Informasi yang Wajib Disediakan dan Diumumkan}

Pasal 9 (1) Setiap Badan Publik wajib mengumumkan Informasi Publik secara berkala. (2) Informasi Publik sebagaimana dimaksud pada ayat (1) meliputi (a) informasi yang berkaitan dengan Badan Publik; (b) informasi mengenai kegiatan dan kinerja Badan Publik terkait; (c) informasi mengenai laporan keuangan; dan/atau (d) informasi lain yang diatur dalam peraturan perundangan. (3) Kewajiban memberikan dan menyampaikan Informasi Publik sebagaimana dimaksud ayat 2 dilakukan paling singkat 6 bulan sekali. (4) Kewajiban menyebarluaskan informasi publik sebagaimana dimaksud ayat 1 , disampaikan dengan cara yang mudah dijangkau oleh masyarakat dan dalam bahasa yang mudah dipahami. (5) Cara sebagaimana dimaksud ayat 4 ditentukan lebih lanjut oleh Pejabat Pengelola Informasi dan Dokumentasi di Badan Publik terkait. (6) Ketentuan lebih lanjut mengenai kewajiban Badan Publik memberikan dan menyampaikan Informasi Publik secara berkala sebagaimana dimaksud pada ayat 1, 2, dan 3 diatur dengan Petunjuk Teknis Komisi Informasi.

\section{5) Informasi yang Wajib Diumumkan dan Tersedia secara Serta-merta}

Pasal 10 (1) Badan Publik wajib mengumumkan secara serta-merta suatu informasi yang dapat mengancam hajat hidup orang banyak dan ketertiban umum. (2) Kewajiban menyebarluaskan Informasi Publik sebagaimana dimaksud pada ayat (1) disampaikan dengan cara yang mudah dijangkau oleh masyarakat dan dalam bahasa yang mudah dipahami. Pasal 11 (1) Badan Publik wajib menyediakan informasi publik setiap saat yang meliputi (a) daftar seluruh informasi publik yang 
berada di bawah penguasaannya, tidak termasuk informasi yang dikecualikan; (b) hasil keputusan Badan Publik dan pertimbangannya; (c) seluruh kebijakan yang ada berikut dokumen pendukungnya; (d) rencana kerja proyek termasuk di dalamnya perkiraan pengeluaran tahunan Badan Publik; (e) perjanjian Badan Publik dengan pihak ketiga; (f) informasi dan kebijakan yang disampaikan Pejabat Publik dalam pertemuan yang terbuka untuk umum; (g) prosedur kerja pegawai Badan Publik yang berkaitan dengan pelayanan masyarakat; dan/atau (h) laporan mengenai pelayanan akses informasi publik sebagaimana diatur dalam UU ini. (2) Informasi Publik yang telah dinyatakan terbuka bagi masyarakat berdasarkan mekanisme keberatan dan/atau penyelesaian sengketa sebagaimana dimaksud dalam Pasal 48, 49, dan 50 dinyatakan sebagai informasi publik yang dapat diakses oleh pengguna informasi publik. (3) Ketentuan lebih lanjut mengenai tata cara pelaksanaan kewajiban badan publik menyediakan informasi publik yang dapat diakses oleh pengguna informasi publik sebagaimana dimaksud pada ayat 1 dan 2 diatur dengan Petunjuk Teknis Komisi Informasi. Pasal 12 Setiap tahun Badan Publik wajib mengumumkan layanan informasi, yang meliputi (a) jumlah permintaan informasi yang diterima; (b) waktu yang diperlukan Badan Publik dalam memenuhi setiap permintaan informasi; (c) jumlah pemberian dan penolakan permintaan informasi; dan/atau (d) alasan penolakan permintaan informasi. Pasal 13 (1) Untuk mewujudkan pelayanan cepat, tepat, dan sederhana setiap Badan Publik (a) menunjuk Pejabat Pengelola Informasi dan Dokumentasi; dan (b) membuat dan mengembangkan sistem penyediaan layanan informasi secara cepat, mudah, dan wajar sesuai dengan petunjuk teknis standar layanan informasi publik yang berlaku secara nasional. (2) Pejabat pengelola informasi dan dokumentasi sebagaimana ayat 1 huruf a dibantu oleh pejabat fungsional. Pasal 14 Informasi Publik yang wajib disediakan oleh Badan Usaha Milik Negara (BUMN), Badan Usaha Milik Daerah (BUMD) dan/atau badan usaha lainnya yang dimiliki oleh negara dalam UU ini adalah (a) nama dan tempat kedudukan, maksud dan tujuan serta jenis kegiatan usaha, jangka waktu pendirian, dan permodalan, sebagaimana tercantum dalam anggaran dasar; (b) nama lengkap pemegang saham, anggota direksi, dan anggota dewan komisaris perseroan; (c) laporan tahunan, laporan keuangan, neraca laporan laba rugi, dan laporan tanggung jawab sosial perusahaan yang telah diaudit; (d) hasil penilaian oleh auditor eksternal, lembaga pemeringkat kredit dan lembaga 
pemeringkat lainnya; (e) sistem dan alokasi dana remunerasi anggota komisaris/dewan pengawas dan direksi; (f) mekanisme penetapan direksi dan komisaris/dewan pengawas; (g) kasus hukum yang berdasarkan UU terbuka sebagai informasi publik; (h) pedoman pelaksanaan tata kelola perusahaan yang baik berdasarkan prinsip transparansi, akuntabilitas, pertanggungjawaban, kemandirian, dan kewajaran; (i) pengumuman penerbitan efek yang bersifat utang; (j) penggantian akuntan yang mengaudit perusahaan; $(\mathrm{k})$ perubahan tahun fiskal perusahaan; (l) kegiatan penugasan pemerintah dan/atau kewajiban pelayanan umum atau subsidi; (m) mekanisme pengadaan barang dan jasa; dan/atau (n) informasi lain yang ditentukan oleh UU yang berkaitan dengan BUMN/BUMD.

Pasal 15 Informasi Publik yang wajib disediakan oleh parpol adalah (a) asas dan tujuan; (b) program umum dan kegiatan partai politik; (c) nama, alamat dan susunan kepengurusan dan perubahannya; (d) pengelolaan dan penggunaan dana yang bersumber dari APBN/APBD; (e) mekanisme pengambilan keputusan partai; (f) keputusan partai yang berasal dari hasil muktamar/kongres/munas dan/atau keputusan lainnya yang menurut AD/ART partai terbuka untuk umum; dan/atau (g) informasi lain yang ditetapkan oleh UU yang berkaitan dengan parpol. Pasal 16 Informasi Publik yang wajib disediakan oleh organisasi nonpemerintah dalam UU adalah (a) asas dan tujuan; (b) program dan kegiatan organisasi; (c) nama, alamat, susunan kepengurusan, dan perubahannya; (d) pengelolaan dan penggunaan dana yang bersumber dari APBN/APBD, sumbangan masyarakat, dan/atau sumber luar negeri; (e) mekanisme pengambilan keputusan organisasi; (f) keputusan organisasi; dan/atau (g) informasi lain yang ditetapkan oleh peraturan perundangan.

\section{Pembahasan}

Pembahasan dalam naskah ini meliputi informasi yang dikecualikan, informasi yang tidak dikecualikan, mekanisme memperoleh informasi, pelaksanaan keterbukaan informasi publik, dan urgensi keterbukaan informasi publik di bidang ekonomi.

\section{1) Informasi yang Dikecualikan}

Pasal 17 Setiap Badan Publik wajib membuka akses bagi setiap Pemohon Informasi Publik untuk mendapatkan Informasi Publik, kecuali (a) Informasi Publik yang apabila dibuka dan diberikan kepada Pemohon Informasi Publik dapat menghambat proses penegakan 
hukum, yaitu informasi yang dapat (1) menghambat proses penyelidikan dan penyidikan suatu tindak pidana; (2) mengungkapkan identitas informan, pelapor, saksi, dan/atau korban yang mengetahui adanya tindak pidana; (3) mengungkapkan data intelijen kriminal dan rencana yang berhubungan dengan pencegahan dan penanganan segala bentuk kejahatan transnasional; (4) membahayakan keselamatan dan kehidupan penegak hukum dan/atau keluarganya; dan/atau (5) membahayakan keamanan peralatan, sarana, dan/atau prasarana penegak hukum. (b) Informasi Publik yang apabila dibuka dan diberikan kepada Pemohon Informasi Publik dapat mengganggu kepentingan perlindungan hak atas kekayaan intelektual dan perlindungan dari persaingan usaha tidak sehat; (c) Informasi Publik yang apabila dibuka dan diberikan kepada Pemohon Informasi Publik dapat membahayakan pertahanan dan keamanan negara, yaitu (1) informasi tentang strategi, intelijen, operasi, taktik dan teknik yang berkaitan dengan penyelenggaraan sistem pertahanan dan keamanan negara, meliputi tahap perencanaan, pelaksanaan dan pengakhiran atau evaluasi dalam kaitan dengan ancaman dari dalam dan luar negeri; (2) dokumen yang memuat tentang strategi, intelijen, operasi, teknik dan taktik yang berkaitan dengan penyelenggaraan sistem pertahanan dan keamanan negara yang meliputi tahap perencanaan, pelaksanaan dan pengakhiran atau evaluasi; (3) jumlah, komposisi, disposisi atau dislokasi kekuatan dan kemampuan dalam penyelenggaraan sistem pertahanan dan keamanan negara serta rencana pengembangannya; (4) gambar dan data tentang situasi dan keadaan pangkalan dan/atau instalasi militer; (5) data perkiraan kemampuan militer dan pertahanan negara lain terbatas pada segala tindakan dan/atau indikasi negara tersebut yang dapat membahayakan kedaulatan NKRI dan/atau data terkait kerja sama militer dengan negara lain yang disepakati dalam perjanjian tersebut sebagai rahasia atau sangat rahasia; (6) sistem persandian negara; dan/atau (7) sistem intelijen negara, (d) Informasi Publik yang apabila dibuka dan diberikan kepada Pemohon Informasi Publik dapat mengungkapkan kekayaan alam Indonesia; (e) Informasi Publik yang apabila dibuka dan diberikan kepada Pemohon Informasi Publik, dapat merugikan ketahanan ekonomi nasional (1) rencana awal pembelian dan penjualan mata uang nasional atau asing, saham dan aset vital milik negara; (2) rencana awal perubahan nilai tukar, suku bunga, dan model operasi institusi keuangan; (3) rencana awal perubahan suku bunga bank, pinjaman pemerintah, perubahan pajak, tarif atau 
pendapatan negara/daerah lainnya; (4) rencana awal penjualan atau pembelian tanah atau properti; (5) rencana awal investasi asing; (6) proses dan hasil pengawasan perbankan, asuransi atau lembaga keuangan lainnya; dan/atau (7) hal-hal yang berkaitan dengan proses pencetakan uang. (f) Informasi Publik yang apabila dibuka dan diberikan kepada Pemohon Informasi Publik, dapat merugikan kepentingan hubungan luar negeri (1) posisi, daya tawar dan strategi yang akan dan telah diambil oleh negara dalam hubungannya dengan negosiasi internasional; (2) korespondensi diplomatik antarnegara; (3) sistem komunikasi dan persandian yang dipergunakan dalam menjalankan hubungan internasional; dan/atau (4) perlindungan dan pengamanan infrastruktur strategis Indonesia di luar negeri. (g) Informasi Publik yang apabila dibuka dapat mengungkapkan isi akta otentik yang bersifat pribadi dan kemauan terakhir ataupun wasiat seseorang; (h) Informasi Publik yang apabila dibuka dan diberikan kepada Pemohon Informasi Publik dapat mengungkap rahasia pribadi, yaitu (1) riwayat dan kondisi anggota keluarga; (2) riwayat, kondisi dan perawatan, pengobatan kesehatan fisik, dan psikis seseorang; (3) kondisi keuangan, aset, pendapatan, dan rekening bank seseorang; (4) hasil-hasil evaluasi sehubungan dengan kapabilitas, intelektualitas, dan rekomendasi kemampuan seseorang; dan/atau (5) catatan yang menyangkut pribadi seseorang yang berkaitan dengan kegiatan satuan pendidikan formal dan satuan pendidikan nonformal. (i) memorandum atau surat-surat antar- Badan Publik atau intra Badan Publik, yang menurut sifatnya dirahasiakan kecuali atas putusan Komisi Informasi atau pengadilan; (j) informasi yang tidak boleh diungkapkan berdasarkan UU.

Poin (j) ini mendapat respon berupa pengujian oleh Komisi untuk Orang Hilang dan Korban Tindak Kekerasan (Kontras) pada laporan penilaian akses informasi publik di lima komisi Negara (Komnas HAM, Kompolnas, Komisi Yudisial, Komisi Kejaksaan, dan Komisi Ombudsman RI) pada Selasa 26 November 2013. Menurut peneliti Kontras, Arief Nur Fikri, lima komisi Negara perlu membuat standar tata cara uji konsekuensi untuk menetapkan informasi yang dikecualikan. Proses itu dapat memastikan tidak ada kesemena-menaan komisi negara untuk menolak permintaan informasi dengan alasan informasi itu masuk kategori dikecualikan (Kompas, 27 November 2013, hlm.3). 


\section{2) Informasi yang Tidak Dikecualikan}

Pasal 18 (1) tidak termasuk dalam kategori informasi yang dikecualikan adalah informasi berikut (a) putusan badan peradilan; (b) ketetapan, keputusan, peraturan, surat edaran, ataupun bentuk kebijakan lain, baik yang tidak berlaku mengikat maupun mengikat ke dalam ataupun ke luar serta pertimbangan lembaga penegak hukum; (c) surat perintah penghentian penyidikan (SP 3) atau penuntutan; (d) rencana pengeluaran tahunan lembaga penegak hukum; (e) laporan keuangan tahunan lembaga penegak hukum; (f) laporan hasil pengembalian uang hasil korupsi; dan/atau (g) informasi lain sebagaimana dimaksud dalam Pasal 11 ayat (2). (2) Tidak termasuk informasi yang dikecualikan sebagaimana dimaksud Pasal 17 huruf $g$ dan $h$, antara lain apabila (a) pihak yang rahasianya diungkap memberikan persetujuan tertulis; dan/atau (b) pengungkapan berkaitan dengan posisi seseorang dalam jabatan publik. (3) Dalam hal kepentingan pemeriksaan perkara pidana di pengadilan, kepolisian, Jaksa Agung, Ketua MA, Ketua KPK, dan/atau Pimpinan Lembaga Negara Penegak Hukum lainnya yang diberi kewenangan oleh UU dapat membuka informasi yang dikecualikan sebagaimana dimaksud dalam Pasal 17 huruf a, b, c, d, e, f, i, dan j. (4) Pembukaan informasi yang dikecualikan sebagaimana ayat 3 dilakukan dengan cara mengajukan permintaan izin kepada Presiden. (5) Permintaan izin sebagaimana dimaksud pada ayat 3 dan 4 untuk kepentingan pemeriksaan perkara perdata yang berkaitan dengan keuangan atau kekayaan negara di pengadilan, permintaan izin diajukan oleh Jaksa Agung sebagai pengacara negara kepada Presiden. (6) Izin tertulis sebagaimana dimaksud pada ayat 3, 4, dan 5 diberikan oleh Presiden kepada Kapolri, Jaksa Agung, Ketua KPK, Pimpinan Lembaga Negara Penegak Hukum lainnya atau Ketua MA. (7) Dengan mempertimbangkan kepentingan pertahanan dan keamanan negara dan kepentingan umum, Presiden dapat menolak permintaan informasi yang dikecualikan sebagaimana dimaksud ayat 3, 4, dan 5. Pasal 19 Pejabat Pengelola Informasi dan dokumentasi di setiap badan publik wajib melakukan pengujian tentang konsekuensi sebagaimana dimaksud dalam Pasal 17 dengan saksama dan penuh ketelitian sebelum menyatakan informasi publik tertentu dikecualikan untuk diakses oleh setiap orang. 


\section{3) Mekanisme Memperoleh Informasi}

Pasal 21 Mekanisme untuk memperoleh informasi publik didasarkan pada prinsip cepat, tepat waktu, dan biaya ringan. Pasal 22 (1) Setiap Pemohon Informasi Publik dapat mengajukan permintaan untuk memperoleh Informasi Publik kepada Badan Publik terkait secara tertulis atau tidak tertulis. (2) Badan Publik wajib mencatat nama dan alamat Pemohon Informasi Publik, subjek dan format informasi serta cara penyampaian informasi yang diminta oleh Pemohon Informasi Publik. (3) Badan Publik yang bersangkutan wajib mencatat permintaan Informasi Publik yang diajukan secara tidak tertulis. (4) Badan Publik terkait wajib memberikan tanda bukti penerimaan permintaan Informasi Publik sebagaimana ayat 1 dan 3 berupa nomor pendaftaran pada saat permintaan diterima. (5) Dalam hal permintaan disampaikan secara langsung atau melalui surat elektronik, nomor pendaftaran diberikan saat penerimaan permintaan. (6) Dalam hal permintaan disampaikan melalui surat, pengiriman nomor pendaftaran dapat diberikan bersamaan dengan pengiriman informasi. (7) Paling lambat 10 hari kerja sejak diterimanya permintaan, Badan Publik yang bersangkutan wajib menyampaikan pemberitahuan tertulis yang berisikan (a) informasi yang diminta berada di bawah penguasaannya ataupun tidak; (b) Badan Publik wajib memberitahukan Badan Publik yang menguasai informasi yang diminta apabila informasi yang diminta tidak berada di bawah penguasaannya dan Badan Publik yang menerima permintaan mengetahui keberadaan informasi yang diminta; (c) penerimaan atau penolakan permintaan dengan alasan yang tercantum sebagaimana dimaksud Pasal 17; (d) dalam hal permintaan diterima seluruhnya atau sebagian dicantumkan materi informasi yang akan diberikan; (e) dalam hal suatu dokumen mengandung materi yang dikecualikan sebagaimana dimaksud dalam Pasal 17, maka informasi yang dikecualikan tersebut dapat dihitamkan dengan disertai alasan dan materinya; (f) alat penyampai dan format informasi yang akan diberikan; dan/atau (g) biaya serta cara pembayaran untuk memperoleh informasi yang diminta. (8) Badan Publik yang bersangkutan dapat memperpanjang waktu untuk mengirimkan pemberitahuan sebagaimana dimaksud ayat 7, paling lambat tujuh hari kerja berikutnya dengan memberikan alasan secara tertulis. 


\section{4) Pelaksanaan Keterbukaan Informasi Publik}

Sebagian besar badan publik belum siap melaksanakan UU KIP. Sebagaimana hasil kerja lapangan Sekretariat Nasional Forum Indonesia untuk Transparansi Anggaran (Seknas Fitra) yang meminta informasi anggaran pada 119 badan publik tingkat nasional dari kementerian, lembaga negara hingga parpol hasilnya mengecewakan. Dari 118 badan publik, 54 atau 45,8 persen memberikan cukup informasi, meskipun sejumlah kecil yang memberi informasi setelah diajukan keberatan dan dilakukan mediasi. Sebagian besar parpol dan lembaga nonstruktural tidak mau memberikan informasi anggaran. Dari 10 parpol yang memiliki kursi di DPR, hanya 2 yang merespon permintaan terkait informasi anggaran yang mereka terima dari APBN yakni PKS dan Partai Gerindra. Tujuh partai lain tak memberi respon meski sudah disampaikan keberatan ke Komisi Informasi Pusat (KIP). Setelah mediasi oleh KIP, PKB mau memberikan informasi. Terdapat 4 kasus KIP yang ditangani KIP dan mendapat putusan berkekuatan hukum tetap yakni harus dibuka yaitu dana BOS (Bantuan Operasional Sekolah), rekening tak wajar milik petinggi Polri, kontrak kerja sama BUMD dengan pihak ketiga di Blok Cepu, dan lembar kerja jawaban komputer seleksi CPNS (Kompas, 3 Agustus 2011, hlm.4). Ketua KIP Pusat Abdulhamid Dipopramono menyatakan, sebagian besar organisasi badan publik belum mempunyai kesadaran untuk memberikan informasi seluasluasnya kepada masyarakat, bahkan cenderung menahan informasi, tak bedanya terhadap sesama komisi negara, termasuk KIP. Kamis 12 Desember 2013 Wapres Boediono menganugerahkan Keterbukaan Informasi Badan Publik 2013 di Istana Wapres. Peserta dibagi dalam empat kategori, yakni badan publik pemerintah, badan publik provinsi, badan publik BUMN, dan badan publik parpol nasional. Dari 12 parpol yang dikirimi kuesioner, hanya PDI-P yang mengembalikan pada KIP (Kompas, 13 Desember 2013, hlm.2). Berbeda dengan Kabupaten Batang Jateng yang menggelar Festival Anggaran agar publik mengetahui program apa saja yang dikerjakan pemda. Daftar anggaran dipajang di halaman kantor Bupati Yoyok Riyo Sudibyo -dilantik Januari 2012- pada 12 s.d 14 Februari 2014. Gaji bupati per bulan Rp 6.231 .700 dan wabup Rp 5.263.700, dan gaji jajaran birokrasi pun dipampang. Tujuan membuka APBD untuk mempertanggungjawabkan kinerjanya kepada masyarakat (Kompas, 1 Maret 2014). KIP Jawa Tengah pada Senin 16 Desember 2013 mengumumkan peringkat daftar transparansi badan publik pemerintah kab/kota di Jateng. Kabupaten Rembang meraih nilai 
tertinggi (terbaik) dengan skor 93, Grobogan dengan skor 88, dan Pemkot Surakarta dengan skor 84, disusul Jepara dan Pemkot Semarang dengan skor sama-sama 82. Urutan terbawah ditempati Pemkab Purbalingga dengan nilai 56. Pemeringkatan berdasarkan dua sumber yakni hasil monitoring dan evaluasi (monev) KIP Jateng di 35 kab/kota dan penilaian atas konten website pemerintah daerah. Monev mencatat kelengkapan regulasi tentang pejabat pengelola informasi dan dokumentasi (PPID) dan sarana meliputi meja pelayanan informasi dan papan pengumuman. Regulasi PPID meliputi peraturan dan surat keputusan bupati/wali kota, standar operasional prosedur (SOP) pelayanan informasi dan uji konsekuensi yang menghasilkan daftar informasi yang dikecualikan. Penilaian website meliputi domain resmi pemkab/pemkot yang mencantumkan menu atau link PPID. Tujuan pemeringkatan menurut Ketua KPID Jateng Rahmulyo Adiwibowo adalah memacu badan publik agar mampu meningkatkan pelayanan informasi (Suara Merdeka, 17 Desember 2013, hlm.12). -Tujuh anggota KPID Jateng terpilih periode 2014 s.d 2017 hasil pilihan Komisi A DPRD Jateng dengan voting pada Rabu, 8 Januari 2014; Asep Cuwantoro memperoleh 11 suara, Mulyo Hadi Purnomo 10, Setiawan Hendra Kelana, Tazkiyyatul Muthmainnah dan Achmad Junaidi 9, Pudjo Rahayu dan Budi Setyo Purnomo 8 suara-.

Riset indeks transparansi informasi publik oleh Fitra bersama Partnership for Governance Reform pada Juni-September 2013 di 98 kabupaten di 5 provinsi (Kalbar, Jateng, NTT, Aceh, Sumut) dengan metode penelusuran situs (website tracking). Hasilnya menempatkan Kebumen sebagai kabupaten dengan nilai tertinggi $(48,25)$ dari skala penilaian 0-100. Kabupaten di Jateng mendominasi posisi 10 besar terbaik secara nasional, secara berurutan: Kebumen, Jepara, Nagan Raya, Kudus, Labuhan Batu, Purworejo, Sikka, Magelang, Cilacap, dan Pemalang. Adapun peringkat teratas dalam daftar pemerintah paling berintegritas berdasarkan survei KPK 2013 teratas diraih Kota Bitung Sulawesi Utara disusul Surabaya Jatim, dan Parepare Sulsel. Upaya berupa perbaikan mekanisme pengaduan masyarakat, penggunaan teknologi informasi untuk mempermudah layanan serta perilaku birokrat, layanan pengadaan barang dan jasa, dan pengguna layanan dalam upaya pencegahan korupsi (Kompas, 17 Desember 2013, hlm.23). 


\section{5) Dampak Tidak Terbukanya Informasi}

Akses publik terhadap sumber dan penggunaan dana lembaga negara yang bersumber dari APBN/APBD oleh lembaga negara seharusnya dibuka secara lebar sesuai aturan main yang tertuang dalam UU KIP. Tidak transparannya penyelenggara negara menyimpan persoalan karena rentan disalahgunakan oleh oknum yang tak bertanggung jawab. Forum Indonesia untuk Transparansi Anggaran (Fitra) menemukan empat potensi kebocoran APBN 2013 yang rentan dimanfaatkan untuk kepentingan politik dalam Pemilu 2014. Pertama, BUMN menjadi sapi perahan karena ketidaktransparanan. Dari perhitungan anggaran 2012, nilai penyertaan modal negara mencapai Rp 677,3 triliun. Dari perhitungan BUMN, ternyata ada laba yang ditahan sebesar Rp 407,5 triliun dan ada niat di kalangan BUMN untuk menggunakan anggaran sebagai dana untuk kepentingan politik. Hal ini terbukti pengajuan uji materi UU Keuangan Negara yang dipisahkan dari keuangan negara sehingga tunduknya pada UU Perseroan Terbatas (PT). Terdapat 15 BUMN yang tak rugi tetapi tidak menyetorkan laba dalam kurun waktu 2010-2012 padahal diberi tambahan penyertaan modal negara dengan total Rp 4.308 triliun. Kedua, ada alokasi dana optimalisasi sebesar Rp 26,9 triliun yang syarat kepentingan menjelang tahun 2014, tanpa dibarengi evaluasi kinerja kementerian atau lembaga dan berpotensi menjadi dana titipan menjelang Pemilu 2014. Ketiga, program populis dengan total $\mathrm{Rp} 52,9$ triliun berupa bantuan siswa miskin, program keluarga harapan, Sistem Jaminan Sosial Nasional, dan Program Nasional Pemberdayaan Masyarakat (PNPM) yang berpotensi sebagai alat mobilisasi di daerah. Keempat, Fitra menyoroti bantuan sosial Rp 75,7 triliun yang tersebar di 14 kementerian atau lembaga (Kompas, 16 Desember 2013, hlm.4). Hasil penelaahan Badan Akuntabilitas Keuangan Negara (BAKN) terhadap ikhtisar hasil pemriksaan semester I tahun 2013 Badan Pemeriksaan Keuangan (BPK) ditemukan kasus penyimpangan keuangan negara dan tata kelola di 21 obyek pemeriksaan BUMN dengan 510 kasus penyimpangan sebesar Rp 2,69 triliun. Dengan rincian 234 kasus terkait kelemahan sistem pengawasan internal dan 276 kasus terkait ketidakpatuhan terhadap ketentuan perundangan, 28 kasus ketidakefektifan senilai $R p$ 44,75 triliun di beberapa BUMN karena tidak tepat sasaran (Suara Merdeka, 21 November 2013, hlm.2). 


\section{6) Urgensi Keterbukaan Informasi Publik di Bidang Ekonomi}

Pentingnya informasi bagi publik tentu bagian dari upaya untuk mengurangi ketertinggalan publik terhadap dinamika kehidupan berbangsa dan bernegara. Tidak bedanya aspek ekonomi. Dalam konteks pelayanan publik oleh penyelenggara negara di tingkat kabupaten/kota, jenis penilaian mencakup kategori keberadaan pejabat pengelola informasi dan dokumentasi (PPID), pelayanan informasi, website, serta sarana dan prasarana. Untuk PPID mencakup kelengkapan peraturan bupati/wali kota, surat keputusan bupati/wali kota, dan aturan pelayanan informasi (standar operasional prosedur/SOP). Pelayanan informasi meliputi jenis informasi berkala, informasi setiap saat, informasi serta merta, dan daftar informasi yang dikecualikan. Hasil penilaian KPID provinsi berupa pemeringkatan bertujuan meningkatkan kinerja dan kompetisi keterbukaan informasi. Naskah ini mengkhususkan urgensi keterbukaan informasi publik di bidang ekonomi.

\section{a) Sumber dan Syarat Mendapatkan Permodalan dan Persaingan}

Modal merupakan urat nadi di dunia perekonomian. Bagi pelaku usaha, untuk mendapatkan akses informasi untuk mendapatkan modal pelaku usaha membutuhkan setiap saat. Untuk memfasilitasi kebutuhan modal, pengembangan dunia usaha, mengantisipasi terjadinya tindak kriminal, dan mensiasati kurs keuangan (rupiah), dan menghadapi kompetitor sangat penting dipahami. Perihal persaingan pemasaran, Peraturan Menteri Perdagangan Nomor 70/M-DAG/PER/12/2013 tentang Pedoman Penataan dan Pembinaan Pasar Tradisonal, Pusat Perbelanjaan, dan Toko Modern dapat dijadikan pegangan bagi usahawan. Pasal 22 ayat 1 dan 2 (1) mewajibkan pusat perbelanjaan dan toko modern untuk menyediakan barang dagangan produksi dalam negeri paling sedikit 80 persen dari jumlah dan jenis barang yang diperdagangkan, (2) gerai toko modern yang dimiliki dan dikelola sendiri paling banyak 150 gerai, (3) kewajiban pusat perbelanjaan menyediakan atau menawarkan ruang usaha untuk pemasaran barang dengan merek dalam negeri, (4) toko modern dapat menjual barang pendukung usaha utama paling banyak 10 persen serta barang merek sendiri paling banyak 15 persen dari keseluruhan jumlah barang yang dijual di gerao toko modern. Upaya tersebut sebagai upaya mendorong produk lokal, mencegah barang selundupan, produsen dalam negeri 
agar memiliki daya saing, dan pasar lokal menjadi lokomotif perekonomian tidak selalu terdistorsi.

\section{b) Pengembangan Dunia Usaha}

Pengembangan dunia usaha yang dapat dipublikasikan secara terbuka di antaranya upaya pengembangan berupa:

Pertama, wisata syariah. Majelis Ulama Indonesia (MUI) dan Kementerian Pariwisata dan Ekonomi Kreatif (Kemenparekraf) merealisasikan wisata syariah Juni 2013. Di Indonesia ada 9 destinasi wisata berpotensi dipromosikan sebagai destinasi wisata syariah yakni Sumatera Barat, Riau, Lampung, Banten, Jakarta, Jawa Barat, Jawa Timur, Sulawesi Selatan, dan Nusa Tenggara Barat. Karakter wisata syariah di antaranya fasilitas hotel menyediakan musala, kamar hotel tersedia kitab suci, dapur halal, tak menjual minuman keras dan hotel tersebut menerapkan prinsip syariah. Argumen pentingnya wisata syariah karena penganut Islam sekitar 250 juta jiwa atau 88,1 persen dari jumlah penduduk Indonesia dari populasi muslim dunia 1,6 miliar jiwa. Uang yang dihabiskan wisatawan muslim di Indonesia pada 2011 mencapai 126 miliar dolar AS atau 1.227,9 triliun, angka ini lebih besar dari uang yang dikeluarkan oleh wisatawan Cina, AS atau Jerman. Kabupaten Kudus menyiapkan potensi ekonomi kreatif melalui potensi wisata desa di Loram Kulon, Jepang, Kaliputu, Colo, Rahtawu, Kaliwungu, Karangmalang, Terban, dan Wonosoco (Suara Merdeka, 2 Mei 2013, hlm.3).

Kedua, mengoptimalkan industri kreatif meliputi periklanan, kerajinan, desain, fashion, video, film dan fotografi, permainan interaktif, musik, seni pertunjukan, televisi dan radio, riset dan pengembangan. Industri tersebut seharusnya mewujudkan upah yang menyejahterakan pekerja. Ketiga, kearifan lokal (local wisdom) yang diwariskan oleh leluhur di setiap daerah, seperti di Kudus Jateng dapat dikemas lebih dinamis sesuai selera konsumen masa kini. Sebagaimana produk lokal khas Muria Kudus yakni kembang Parijoto yang perlu dikembangkan secara luas dengan mengemas produk lebih mutakhir. Belum lagi jeruk khas Muria Kudus, kayu pengusir tikus yang dihasilkan dari area Gunung Muria. Bahkan situs budaya religius yang dimiliki Kota Kudus karena kiprah Sunan Kudus dan Sunan Muria yakni Masjid al-Aqsha dan Menara Kudus-nya, Masjid Muria dan situs Makam Syekh Sadzali di Rejenu, Desa Japan Kecamatan Dawe, Kudus dan masih banyak lagi. Karya budaya leluhur tersebut dapat 
diberdayakan dengan memahami lima kata kunci membangun Kudus sebagai kota wisata, berupa: melindungi kebudayaan (protect the culture) dan alam (Protect the nature), memberdayakan dan menguntungkan masyarakat (empower and bring benefit to local people), melakukan konservasi (conservation) lingkungan fisik dan nonfisik, dan menciptakan lahan eksotis yakni daya tarik wisata khas dan belum banyak dikenal/dimiliki obyek wisata tempat lain. Kelima konsep tersebut memerlukan kepedulian yang besar bersam dengan Pemkab Kudus mulai dalam bentuk pendanaan, supporting/motivasi mengembangkan kearifan lokal, dan pemberdayaan pelaku wisata dan pelaku usaha berbasis kearifan lokal.

Hal itu tidak hanya diinformasikan melalui dunia maya, tetapi media elektronik, media cetak secara massal dan media lain yang dapat diakses oleh publik, tidak hanya di kota dan yang melek huruf, juga publik yang berada di pedesaan dan jauh dari akses dunia maya, terutama yang tidak melek huruf.

\section{c) Mengantisipasi Terjadinya Tindak Kriminal}

Penggunaan teknologi informasi sebagai media informasi publik secara luas dapat mengurangi terjadinya tindak kriminal berupa korupsi atau lainnya. Hal ini dikarenakan data dapat diakses oleh setiap orang dalam ruang dan waktu tak terbatas sehingga dengan mudah dilakukan evaluasi dan klarifikasi jika terjadi kejanggalan penggunaan anggaran. Begitu pula bila informasi tentang pelanggaran hukum lainnya, tetapi bentuk pelanggaran tersebut diinformasikan kepada publik secara luas maka tindak kriminal akan tercegah. Sebagaimana muatan UU Nomor 5 Tahun 1999 tentang Konservasi Sumber Daya Alam Hayati dan Ekosistem Pasal 21 ayat 2 huruf a jo Pasal 40 ayat 2 dan PP Nomor 7 Tahun 1999 bahwa satwa yang dilindungi (tidak boleh diperjualbelikan) berupa kucing emas (hidup di wilayah Asia Tenggara), kucing hutan, burung hantu, burung alap-alap, burung elang, kijang, landak, trenggiling, kukang, beruang madu (khas di Provinsi Bengkulu), harimau Sumatera (di Sumatera), macan tutul, macan dahan (di Kalimantan dan Sumatera), kijang muntjak, kambing hutan (di Sumatera), dan burung rangkong.

\section{d) Urgensi Dunia Maya sebagai Pemasok Informasi Publik}

Seiring dengan perkembangan alat teknologi di bidang informasi, pemasok informasi dapat memerankan media sosial (layanan yang 
dapat menghubungkan orang per orang dan sekupnya luas untuk diakses publik) secara online (akses langsung) sebagai sumber informasi seperti black berry messanger (BBM), facebook (FB), twitter atau lainnya. Kondisi tersebut direspon oleh perusahaan telekomunikasi global seperti Microsoft, Yahoo, Google, Facebook, Apple, Skype, Youtube, Verizon, AT\&T, dsb. Pengguna informasi melalui dunia maya tersebut lintas batas wilayah sehingga memiliki nilai manfaat dengan prinsip cepat, akurat, dan tidak meluangkan waktu untuk mobilisasi publik. Hal ini merupakan imbas revolusi informasi yang dimotori oleh perkembangan teknologi komputer, telekomunikasi bergerak, dan sistem posisi global. Revolusi ini mengubah cara kita berinteraksi yang telah menghilangkan dimensi ruang. Teknologi ini memungkinkan penyebaran informasi secara langsung menjangkau banyak orang.

Pengguna internet di Asia berdasarkan data Internet World Stats hingga Desember 2011 tertinggi adalah Jepang (101,2 juta), India (121 juta), China (513 juta), dan Indonesia (55 juta) pengguna. Menurut staf ahli Kemenkoinfo, Kalamullah Ramli, pengguna internet di Indonesia pada 2012 terdapat 62,5 juta orang, 67 persennya berusia 14-24 tahun dan 23 persen berusia 25-34 tahun (Kompas, 29 Mei 2013, hlm.12). Data International Telecommunication Union, pengguna Ponsel dunia pada 2010 mencapai 5,4 miliar, pada 2012 mencapai 6,8 miliar. Diprediksi pada 2013 mencapai 7,5 miliar dan 2016 diprediksi mencapai 8,5 miliar. Pada 2013 52,3 persen pengguna ponsel di Asia Pasific, terbanyak di China (1,1 miliar) dan India (906 juta). Pada 2016 diprediksi mencapai 54,3 persen. Pelanggan Ponsel di Indonesia per Desember 2012 menurut MobiThinking mencapai 260 juta dengan penduduk per Desember 2012 sebanyak 242,3 juta. Dengan demikian, jumlah pnsel yang beredar lebih tinggi daripada jumlah penduduk yakni 107,3 persen karena seorang memiliki lebih dari satu ponsel. Dari jumlah tersebut, 47,6 juta atau 19 persen pengguna 3G/3,5 G.

Pemanfaatan ponsel dikembangkan untuk jejaring sosial (facebook, twitter, foursquare, instagram, dan Path) yang mendongkrak penjualan ponsel pintar (smartphone) yang dapat digunakan untuk mengakses internet, berkamera, membaca teks dalam bentuk word, excel, dsb. Bahkan media ngobrol online dapat dimanfaatkan di Yahoo Messenger, WhatsApp, WeChat, Kako Talk, dan Line yang semua aplikasinya dapat diunduh di ponsel pintar, tanpa SMS. Akses internet yang tersedia di berbagai tempat memudahkan pengguna ponsel pintar mengoptimalkan perangkatnya untuk bekerja dan menikmati hobi. Ponsel pintar 
berkembang sejak tahun 2000 diawali hadirnya Ericsson T36 yang memiliki Bluetooth, tahun 2002 muncul ponsel pintar Blackberry 5810, Blackberry PDA pertama memiliki konektivitas seluler dengan jaringan GSM, memudahkan kirim dengan elektronik, mengelola data, dan mempersiapkan memo. Tahun 2002 juga muncul ponsel pintar berkamera, seperti Sanyo SCP-5300 dengan resolusi 640x480 dan hanya $4 x$ digital zoom (masih sederhana). Tahun 2007 Apple memunculkan ponsel pintar iPhone yang mengganti keyboard dan keypad dengan tampilan layar multisentuh. Tahun 2012 ponsel pintar mampu merekam video 1080p, memutar film, dan mobile hotspot bagi perangkat lain. International Data Corporation (IDC) Januari 2013 menyebutkan 5 ponsel pintar terjual adalah Samsung (215,8 juta), Apple (135,9 juta), Nokia (35,1 juta), HTC (32,6 juta), Blaccberry (32,5juta), dan ponsel lain 260,7 juta. Jumlah ponsel pintar total yang terjual pada data Januari 2013 sebanyak 712,6 juta. Kehadiran tablet sempat menimbulkan perdebatan apakah perangkat ponsel atau laptop dengan koneksi 3G. data IDC Desember 2012 tablet terjual 122,3 juta tablet, iOS Apple terjual 53,8 persen, Android 42,7 persen dan Windows 2,9 persen (Adhi, 2013:70). Data ComScore Februari 2012 bahwa 33 persen pengguna jejaring sosial di dunia berada di kawasan Asia Pasific, di Eropa 30 persen, Amerika Utara 18 persen, Amerika Latin 10 persen, dan sisanya di kawasan Timur Tengah dan Afrika hanya 9 persen. Data akhir 2012, 43,8 juta penduduk Indonesia termasuk pengguna jejaring sosial Facebook dengan urutan Amerika, Brazil, India, dan Indonesia. Adapun pengguna twitter Indonesia urutan kelima tertinggi di dunia (Diredja, 2013:71).

Di sisi lain, media sosial mudah dikacaukan oleh tangan jahil untuk kepentingan tertentu, sebagaimana selama 2011-2013 awal, Indonesia diserang sebanyak 3,9 juta kali di dunia maya dari dalam dan luar negeri terhadap beragam situs dan sistem yang dikendalikan pemerintah. Gangguan tersebut mayoritas bermotif ekonomi. Kemenkoinfo mengupayakan perlindungan pada dunia bisnis dan instalasi vital seperti listrik, penerbangan, bursa efek, data penduduk elektronik dari gangguan peretas (Kompas, 3 April 2013, hlm.5). Bahkan situs web Presiden Susilo Bambang Yudhoyono (www.presidensby.info) diretas oleh Wildan Yani Ashari, usia 20 tahun warga Desa Balunglor, Kecamatan Balung, Jember, Jatim diadili di Pengadilan Negeri Jember pada Kamis 11 April 2013. Wildan didakwa lima dakwaan berlapis dan dituduh melanggar UU Telekomunikasi dan UU Informasi dan Transaksi Elektronik. Wildan memuat akun domain Presidensby.info di 
server pihak perusahaan web positioning dan menempatkan file "Jember Hacker Team" di server Jatirejo.com. Akibatnya, para pemakai internet tidak dapat mengakses konten www.presidensby.info tapi konten yang terakses adalah tampilan file HTML Jember Hacker Team. Pada awal April 2013, Presiden SBY menghadirkan dua akun twitter: Istana @Istana Rakyat dan Presiden Susilo Bambang Yudhoyono @ SB Yudhoyono merupakan kehendak presiden menyapa publik dan mencegah terjadinya diskoneksi dengan realitas sosial warga negara.

Data harian Kompas, kriminalitas yang bermula dari media sosial (chatting, friendster, facebook) berupa penipuan, penculikan, perampokan, dan penganiayaan yang berakhir dengan kekerasan seksual bahkan pembunuhan. Terdapat 14 kasus penipuan, 1 kasus pembunuhan, dan 6 kasus kekerasan seksual selama 2002-April 2013 berawal dari 'pertemuan' di media sosial. Pada 2012 Komnas Perlindungan Anak mencatat dari 87 kasus pelecehan seksual terhadap anak, 37 di antaranya berawal dari media sosial. Pada Januari-Feruari 2013 dari 216 laporan kasus kekerasan seksual terhadap anak, 31 kasus berawal dari media sosial. Modusnya berkenalan lewat situs jejaring sosial yang ditindaklanjuti pertemuan 'kopi darat' sehingga terjadi kekerasan seksual, perampokan dan penganiayaan (Kompas,15 April 2013, hlm.27). Menurut Liye, dampak negatif dunia maya menjadi penyakit sosial berupa (1) berkurangnya kualitas dan kuantitas membaca (apalagi menulis teks) mengandalkan akun e-mailnya, (2) suburnya kebiasaan berdebat yang tiada manfaat, (3) tumbuhnya mental gratisan karena mampu mengakses film, lagu dan lainnya secara gratis tanpa memedulikan hak cipta karena asal comot, (4) rendahnya sopan santun karena tak bertatap muka dalam berinteraksi sehingga (sering) menampakkan identitas palsu, (5) mulai kaburnya interaksi dunia nyata, (6) berkurangnya waktu produktif karena terbawa dinamika informasi yang baru dan tidak selalu bermanfaat untuk kehidupan (2013:7).

Langkah Indonesia mensikapinya dengan menyiapkan keamanan siber dan menyusun langkah koordinasi, di antaranya dibentuk Indonesia Security Incident Response Team on Internet Infrastructure (ID-SIRTII) yang melibatkan Kemenhan, Kemeninfokom, dan Lembaga Sandi Negara. Bagi pendakwah mampu memanfaatkan dunia maya sebagai media dakwah yang tepat dan praktis. Dalam konteks global, perang konvensional berupa angkat senjata dengan ledakan bom dan meriam, tetapi dalam era maya dikenal cyber war (perang siber). Sebagaimana sasaran yang 'ditembakkan' pada jaringan milik Amerika berupa 
jaringan listrik, sistem transportasi, jaringan keuangan, dan militer. Kejahatan ini dianggap lebih bahaya daripada kejahatan transnasional, terorisme, dan proliferasi senjata pemusnah massal. Jenderal Keith Alexander, Komite Angkatan Bersenjata, AS yang memimpin Unit Cyber Pentagon bahwa jumlah serangan maya terhadap situs utama AS makin berlipat yakni lebih dari 140 serangan di Wall Street selama Oktober 2012 hingga Maret 2013. Menurut Pimpinan Eksekutif Google, Eric Schmidt bahwa peretas China yang paling canggih dan produktif menyasar perusahaan AS. Begitu pula Amerika menyerang dengan menyebarkan virus Stuxnet pada 2010 disasarkan pada jaringan nuklir Iran (Republika, 18 Maret 2013, hlm.27).

Media online dapat diberi makna media massa yang menyajikan berita/info secara online yang tersedia di website/situs berita. Pada awalnya media online dibuat oleh redaktur media massa cetak untuk memindahkan isi pemberitaan ke website. Media online pertama kali adalah Chicago Online yang diluncurkan oleh Chicago Tribune di Amerika yang tayang perdana pada Mei 1992 sehingga dijuluki The First Newspaper Service on America Online. Adapun media online di Indonesia pertama kali diluncurkan oleh Republika.co.id pada 17 Agustus 1995, disusul Kompas.com., Tempointeraktif.com., Detik.com. Media online tersebut dapat dimanfaatkan sebagai media dakwah. Sebagaimana komunitas Online The Revert Muslims Association (RMA) sejak 2005 tergerak untuk menyelamatkan para calon mualaf ataupun muslimin baru di ranah maya. Mereka membuat situs web menjangkau 85 negara yang bertujuan memberikan pengetahuan keislaman dengan baik dan benar. Web RMA berisi pengetahuan dasar Islam, tata cara ibadah, cerita mualaf, dan forum online untuk memberikan kesempatan para pengunjung web bertanya bebas dan menyampaikan pendapatnya (Republika, 23 Juni 2013, hlm.24).

Besarnya peran dunia maya sebagai media informasi tersebut maka banyak pengembang membuat aplikasi smartphone (telepon pintar) dengan sistem operasi iOS, Android, Windows Phone, maupun BalckBerry yang aplikasinya dapat diunduh melalui App World. Pertama, al-Quran digital yang diberi nama iQur'an Lite. Aplikasi ini dapat diunduh dan dipasang secara gratis pada smartphone berbasis iOS seperti iPhone, iPad atau iPod dan pengguna ponsel Android. Dengan aplikasi ini, pengguna dapat membuka kitab suci al-Quran kapanpun dan di manapun. Aplikasi ini juga menampilkan terjemahan setiap ayat dengan multibahasa disertai audio yang dapat dijadikan 
panduan membaca al-Quran dengan tartil. Pengguna juga dapat menandai batas akhir bacaan (book mark) bila pada kesempatan lain ingin melanjutkan bacaan. Kedua, memandu bagi pengguna untuk menentukan arah kiblat dan mendengar azan jika sudah masuk waktu salat sesuai tempat dan lokasi. Ketiga, doa harian disertai suara atau audio yang memudahkan dalam melafalkan doa. Keempat, aplikasi radio dakwah untuk smartphone Android. Siaran radio yang disediakan aplikasi meliputi Radio Rodja Bogor, Radio Muslim Yogyakarta, Radio Al Iman Surabaya, Radio Hangfin Batam, Radio Assunnah Cirebon, Radio Hidayah Pekan Baru Riau, Radio Suara Quran Solo, Radio Kita Madiun, Radio BASS Salatiga, Radio Nurussunnah Semarang, Radio Arroyyan Gresik, dan Radio Islamic Centre Bin Baz Yogyakarta. Kelima, aplikasi Islam menjawab yang menyajikan kumpulan tanya jawab seputar kehidupan sehari-hari (Suara Merdeka, 8 Juli 2013, hlm.19).

\section{Simpulan}

Keterbukaan Informasi Publik bagi lembaga Negara (termasuk dunia pendidikan) bila lembaga tersebut mendapat bantuan APBN/APBD, lembaga tersebut terikat kewajiban sebagai badan publik. Setiap badan publik wajib mengangkat pejabat pengelola informasi dan dokumentasi (PPID) yang tugas pokonya mendokumentasikan dan melayani permintaan informasi bagi publik. Pemerintah sudah sewajarnya memenuhi amanat UU KIP sebagai penyelenggara Negara yang taat hukum. Hal ini diawali dengan keterbukaan manajemen pemerintahan. Harapannya, tidak muncul kecurigaan antar-berbagai komponen warga negara. Kecurigaan itulah embrio konflik yang mengarah ke disintegrasi. Apabila negara mampu melaksanakan dengan baik dan hasilnya dapat dipahami warga negara dengan baik pula maka mewujudkan pembangunan nasional di bidang informasi publik menjadi kenyataan.

Dunia bisnis dalam mengikuti dinamika memerlukan kiat dan upaya bersama antara pelaku usaha, pemerintah, dan warga negara. Hal ini merupakan satu kesatuan tunggal menuju terwujudnya kesejahteraan rakyat dan pemberdayaan ekonomi. Negara pun dituntut untuk mengevaluasi kinerja organnya dalam melaksanakan amanat UU KIP. 
Moh. Rosyid

\section{DAFTAR PUSTAKA}

Alafghani, Mohammad Mova. Dua Kubu Transparansi. Republika, 28 September 2013.

Diredja, Tjahja Gunawan. Media Sosial untuk Apa? Kompas, 28 Juni 2013.

Liye, Tere. Penyakit Sosial Dunia Maya. Kompas, 6 Juli 2013.

UU Nomor 14 Tahun 2008 tentang Keterbukaan Informasi Publik (KIP) 